\title{
ANALISIS TIPOGRAFI PADA LOGOTYPE BAND FORGOTTEN
}

\author{
Atang Riyan Isnandar ${ }^{1}$, Wantoro ${ }^{2}$ \\ 1,2Program Studi Desain Komunikasi Visual, \\ Universitas Komputer Indonesia Bandung \\ 1atangriyan_isnandar@yahoo.com, ²amwantoro@yahoo.com
}

\begin{abstract}
Abstrak
Forgotten merupakan band asal kota Bandung yang beraliran death metal. Band ini telah memiliki beberapa album yang cukup sukses. Salah satu faktor yang turut berperan penting dalam album-album Forgotten adalah desain sampul album. Sampul album merupakan identitas dan pesan dari musik yang dibawakan oleh Forgotten. Dalam sampul album, terdapat salah satu elemen visual yaitu Tipografi. Salah satu peran tipografi dalam sampul album Forgotten adalah sebagai logotype dari band. Yang menarik, dari lima album yang telah dirilis Forgotten yaitu "Future Syndrome" (1997), "Obsesi Mati" (2000), "Tuhan Telah Mati" (2001), "Tiga Angka Enam" (2003) dan "Laras Perlaya" (2011) adalah tampilan logotype band yang selalu berbeda. Perubahan logotype Forgotten disebabkan oleh beberapa faktor seperti adanya perubahan selera, transformasi musik dan pergantian personil yang dialami oleh band Forgotten. Perubahan ini berakibat pada munculnya kesan visual yang berbeda-beda dari masing-masing logotype di setiap sampul albumnya. Apalagi logotype band dengan genre death metal memiliki kecendrungan yang unik, dekoratif, bahkan sulit untuk dibaca. Oleh karena itu untuk mengetahui kesan visual yang dimunculkan oleh setiap logotype akan dilakukan penelitian dengan pendekatan tipografi. Tujuan dari penelitian ini adalah selain untuk mengetahui perubahan logotype dari kelima sampul album yang telah dirilis oleh Forgotten juga ingin mengetahui kesan visual terhadap tipografi terkait dengan prinsip kejelasan (legibility), keterbacaan (readability) dan kemampuannya untuk dilihat pada jarak tertentu (visibility).
\end{abstract}

Kata Kunci: Sampul Album, Tipografi, Logotype, Forgotten

\begin{abstract}
Forgotten is a band from Bandung, the death metal genre. The band has had some fairly successful album. One of important factor in albums Forgotten is the album cover design. The album cover are the identity and the message of the music performed by the Forgotten. In the cover of the album, there is one visual element called Typography. One role of typography in Forgotten album cover is a logotype of the band. Interestingly, there is change of logotype in five albums that have been released Forgotten namely "Future Syndrome" (1997), "Obsession Dead" (2000), "God is Dead" (2001), "Three Figures Six" (2003) and "Laras Perlaya" ( 2011). Forgotten logotype changes caused by several factors such as the changing tastes, music and transformation experienced by the personnel changes the band Forgotten. These changes resulted in the emergence of the visual impression different from each logotype in all the album artwork. Moreover logotype band with death metal genre has a tendency of unique, decorative, even difficult to read. Therefore, to determine the visual impression that is raised by each logotype will do research with the approach of typography. The purpose of this study was to assess changes in addition to the logotype of the fifth album cover that has been released by Forgotten also want to know the visual impression of the typography related to the principle of clarity (legibility), legibility (readability) and its ability to be seen at a certain distance (visibility).
\end{abstract}

Keywords: Album Cover, Tipography, Logotype, Forgotten 


\section{PENDAHULUAN}

Seperti halnya bidang seni lain seperti seni rupa, seni tari dan sebagainya, musik juga memiliki berbagai macam jenis dan genre. Death metal merupakan sebuah sub-genre dari aliran musik heavy metal yang berkembang dari thrash metal (Syifak, 2012 : para 1). Beberapa ciri khas dari death metal adalah lirik lagu yang bertemakan kegelapan, kematian atau kekerasan, seting suara gitar yang berat \& rendah, tempo lagu yang cepat, dan vokal yang dinyanyikan dengan teknik gerutuan atau geraman (growl).

Salah satu band yang mengusung genre musik death metal adalah Forgotten. Grup musik metal asal kota Bandung ini memiliki karakteristik yang kuat dan menjadi salah satu band yang dikenal oleh para penikmat musik beraliran death metal di Indonesia. Selain faktor-faktor tersebut, faktor lain yang menunjang kesuksesan band Forgotten yaitu desain pada sampul album-albumnya. Kata "sampul" sendiri dalam Kamus Besar Bahasa Indonesia (Pusat Bahasa Depdiknas cetakan 2008) diterjemahkan sebagai "pembungkus dari bahan kertas, plastik, kain, dan sebagainya". Namun, sampul pada saat ini tidak saja berfungsi sebagai pembungkus, namun juga merupakan representasi isi. Sampul album juga merupakan bagian depan dari sebuah kemasan produk rekaman suara yang bersifat komersial (Riyan, 2013).

Dengan peran sampul seperti dipaparkan di atas, sampul album tentunya menjadi salah satu faktor suksesnya suatu band. Desain sampul album yang khas \& menarik, merupakan satu faktor yang membuat Forgotten menjadi popular di masyarakat. Dalam sampul album-album Forgotten yaitu "Future Syndrome" (1997), "Obsesi Mati" (2000), "Tuhan Telah Mati" (2001), "Tiga Angka Enam" (2003) dan "Laras Perlaya" (2011) terdapat elemen visual yang sangat penting yaitu tipografi. Tipografi menjadi hal yang menarik dari desain sampul Forgotten karena adanya perubahan logotype band pada setiap sampul albumnya. Menurut Rustan (2009), istilah logotype sendiri dapat diartikan sebagai tulisan nama entitas yang didesain secara khusus dengan menggunakan teknik lettering atau memakai jenis huruf tertentu. Fungsi dari logotype itu sendiri adalah sebagai :
a. Identitas diri,
b. Tanda kepemilikan,
c. Tanda jaminan kualitas dan
d. Mencegah peniruan / pembajakan.

Berdasarkan paparan di atas, maka penulis ingin mengetahui desain sampul album band Forgotten. Dalam penelitian, permasalahan dibatasi pada analisis logo berupa tipografi (logotype) band Forgotten pada kelima sampul album Forgotten yaitu "Future Syndrome”, "Obsesi Mati", "Tuhan Telah Mati”, "Tiga Angka Enam" dan "Laras Perlaya" yang berbeda-beda. Album-album tersebut dipilih karena merupakan seluruh album yang dimiliki Forgptten hingga saat ini. Kelima logotype di setiap sampul album musik band Forgotten tersebut akan dianalisis berdasarkan prinsip tipografi terkait dengan kejelasan (legibility), keterbacaan (readability) dan kemampuannya untuk dilihat pada jarak tertentu (visibility). Analisis menggunakan prinsip tipografi dipilih karena syarat utama huruf adalah dapat ditangkap secara visual dengan baik sebelum dapat menjadi elemen pembentuk kesan visual sebagai 
logotype. Dengan tingkat kejelasan legibility, readability dan visibility yang baik, sebuah logotype akan lebih mampu mengemban fungsinya dengan baik. Hasil dari penelitian diharapkan dapat memberikan pengetahuan dan pemahaman baru mengenai bidang tipografi khususnya pada logotype pada sebuah band pada media sampul album dan berguna menjadi bahan acuan atau pembanding bagi penelitian sejenis selanjutnya, khususnya dalam bidang Desain Komunikasi Visual.

\section{METODE PENELITIAN}

Penelitian ini merupakan penelitian kualitatif dengan menggunakan analisis visual berbasis prinsip tipografi berdasarkan teori dan pengamatan penulis terhadap objek yang diteliti. Pengumpulan data dilakukan baik melalui wawancara secara langsung kepada Adi Gembel yang merupakan vokalis dari band Forgotten, dokumentasi pribadi, dan penelusuran literatur (offline \& online) terkait.

Dalam analisis logotype Forgotten, akan digunakan prinsip tipografi yaitu legibility, readability \& visibility. Legibility yaitu kemudahan mengenali huruf dan membedakan masing-masing huruf atau karakter. Surianto Rustan (2011 : 74) menyatakan, suatu jenis huruf dikatakan legible apabila masing-masing huruf atau karakter-karakternya mudah dikenali dengan jelas satu sama lain. Rustan (2011 : h.74) menjelaskan bahwa readability berhubungan dengan tingkat keterbacaan suatu teks. Teks yang readable berarti keseluruhannya mudah dibaca. Apabila legibility lebih membahas kejelasan karakter satu-persatu, readability tidak lagi menyangkut huruf atau karakter satupersatu, melainkan keseluruhan teks yang telah disusun dalam suatu komposisi.

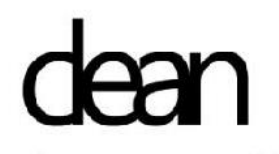

Kerning yang terlalu rapat antara huruf $\mathrm{C}$ dan L seperti huruf $d$

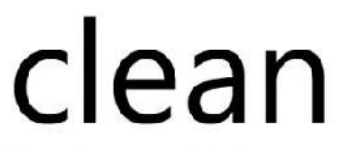

Kerning yang baik membuat kata menjadi lebih mudah terbaca

Gambar 1. Contoh Readability Pada Kata Clean [Sumber : Dokumentasi Atang Ryan Isnandar, 2013]

Sedangkan visibility merupakan kemampuan suatu huruf, kata, atau kalimat dalam suatu karya desain komunikasi visual dapat terbaca dalam jarak baca tertentu. Analisa terhadap masing-masing logotype akan menghasilkan kesimpulan mengenai tingkat yaitu legibility, readability \& visibility yang merupakan faktor pembentuk kesan visual.

\section{ANALISIS TIPOGRAFI}

\subsection{Analisis Logotype Forgotten Pada Sampul Album "Future Syndrome"}

Album Forgotten pertama, berjudul "Future Syndrome" dirilis pada bulan Januari 1997. Album ini direkam di Palapa Studio Bandung dan berisi enam buah lagu dengan lirik berbahasa Inggris. Peredarannya mencakup wilayah Indonesia, Asia dan Eropa. 


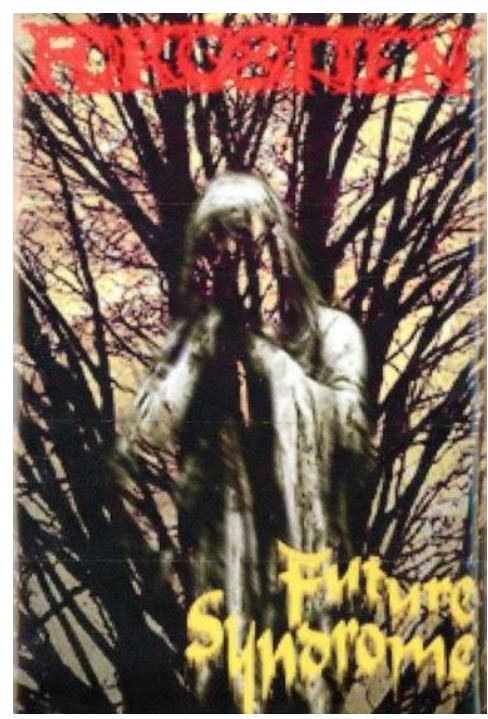

Gambar 2. Sampul Album "Future Syndrome"

[Sumber : http://tembangkenangan.web.id/wp-content/uploads/2010/07/Forgotten-FutureSyndrome-1997.jpg (18 April 2013)]

Logotype band Forgotten pada sampul album "Future Syndrome" ini didesain oleh Dinan pada tahun 1997. Huruf berjenis dekoratif yang digunakan pada logotype dan diaplikasikan pada sampul depan album memakai warna merah dan ditempatkan di bagian atas sampul album.

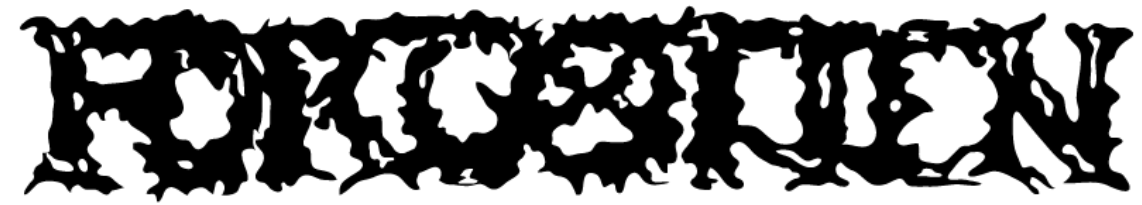

Gambar 3. Logo Band Forgotten pada album "Future Syndrome"

[Sumber : Dokumentasi Atang Ryan Isnandar, 2013]

\section{a. Legibility}

Logotype band Forgotten pada album Future Syndrome memiliki legibility yang kurang baik. Hal ini disebabkan karena bentuk huruf dari logotype tersebut memiliki distorsi bentuk yang cukup ekstrim, sehingga butuh waktu sedikit lebih lama untuk mengenali huruf tersebut meskipun huruf tersebut dalam ukuran besar. Begitupun jika huruf ini digunakan dalam ukuran yang kecil maka pembaca akan sangat sulit mengenali huruf tersebut.
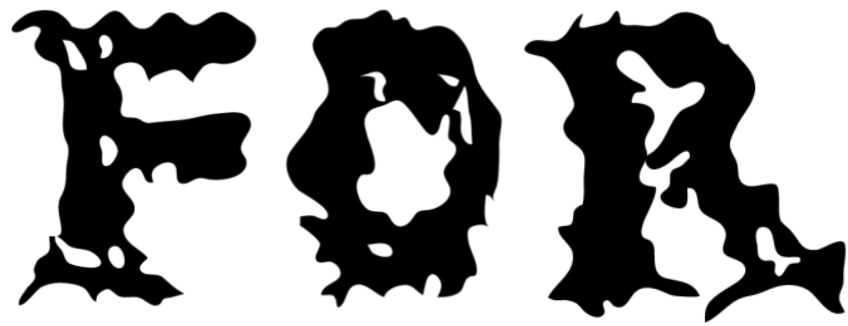

Gambar 4. Legibility pada logo band Forgotten pada album "Future Syndrome"

[Sumber : Dokumentasi Atang Ryan Isnandar, 2013] 


\section{b. Readability}

Readability merupakan tingkat keterbacaan suatu teks. Teks yang readible berarti keseluruhannya mudah dibaca. Readability dipengaruhi oleh kombinasi huruf dan jaraknya. Susunan huruf pada logo Forgotten ini memiliki tingkat readability yang sangat rendah. Kerapatan antar huruf/kerning yang begitu rapat serta penambahan ornamen akar untuk menyambungkan setiap hurufnya menyebaban tulisan Forgotten ini sulit untuk dibaca.

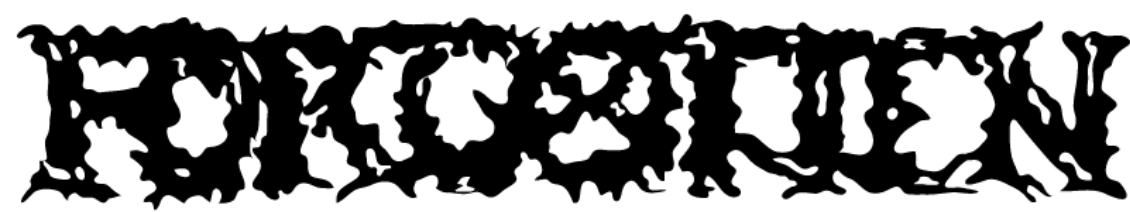

Gambar 5. Readability pada logo band Forgotten pada album "Future Syndrome" [Sumber : Dokumentasi Atang Ryan Isnandar, 2013]

c. Visibility

Visibility berhubungan dengan jarak pandang antara pembaca dengan objek. Semakin jauh jarak pandang maka visibility-nya akan berkurang, namun apabila tingkat legibility dan readability suatu huruf atau katanya baik, maka dengan jarak yang cukup jauh pun akan tetap visible.

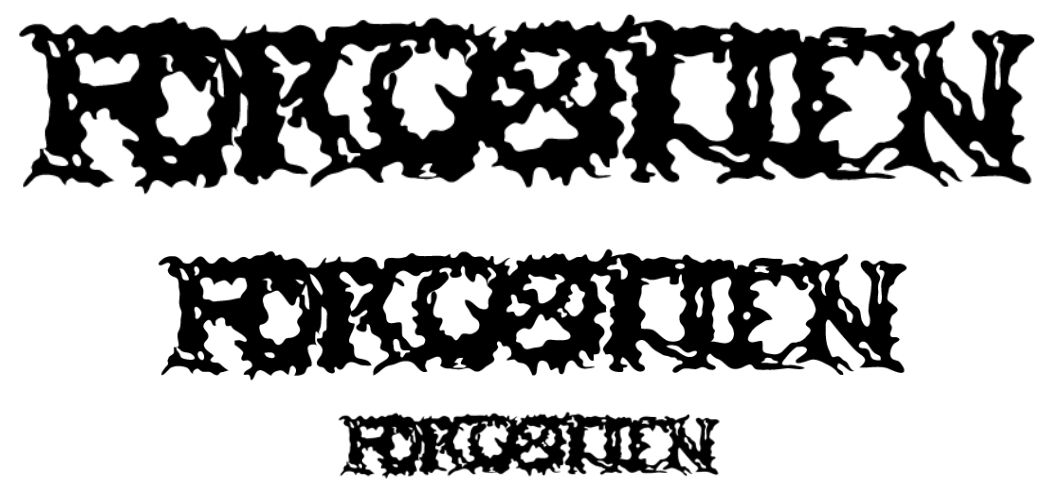

Forox

Gambar 6. Visibility pada logo band Forgotten pada album "Future Syndrome" [Sumber : Dokumentasi Atang Ryan Isnandar, 2013]

Logo Forgotten pada album "Future Syndrome" ini memiliki tingkat visible yang kurang baik. Dengan percobaan skala, dalam jarak pandang kurang lebih $60 \mathrm{~cm}$ logo ini akan sulit untuk dibaca, sedangkan untuk jarak lebih dari $200 \mathrm{~cm}$ logo ini sama sekali tidak akan terbaca. 


\subsection{Analisis Logotype Forgotten Pada Sampul Album "Obsesi Mati"}

Album kedua Forgotten dirilis dibawah label indie lokal Extreme Soul Production pada bulan Agustus 2000 dengan judul "Obsesi Mati". Sampul album kedua ini didesain oleh Opick pada tahun 2000. Jenis huruf yang digunakan untuk logotype pada album ini masih menggunakan huruf berjenis dekoratif dengan distorsi yang nampak lebih menonjol daripada album sebelumnya "Future Syndrome". Logotype pada sampul album "Obsesi Mati" ini ditata di bagian bawah sampul album.

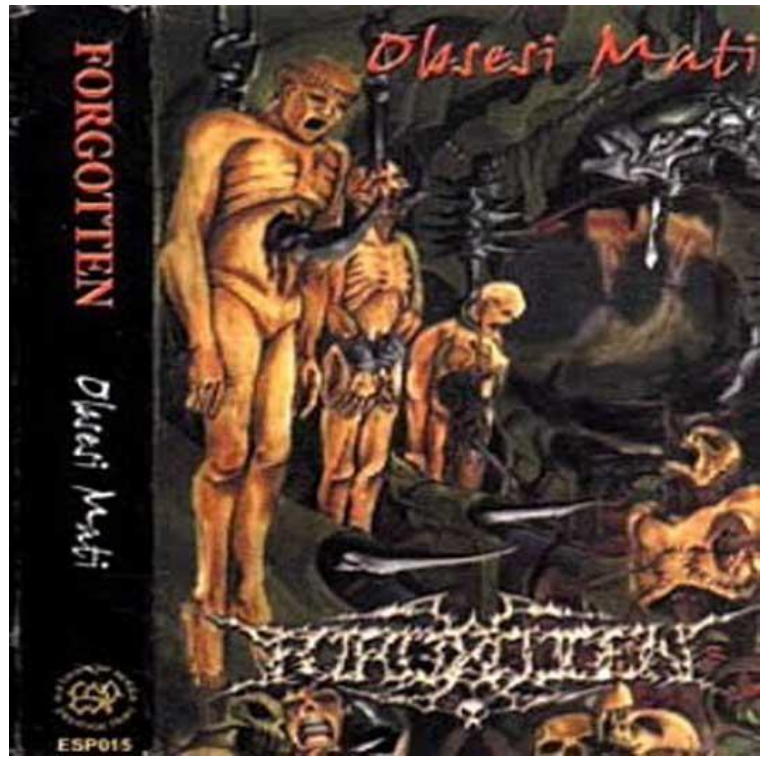

Gambar 7. Sampul Album "Obsesi Mati”

[Sumber : http://bandung-underground.com/wp-content /uploads/2012/02/Forgotten-Obsesi-Mati.jpg (18 April 2013)]

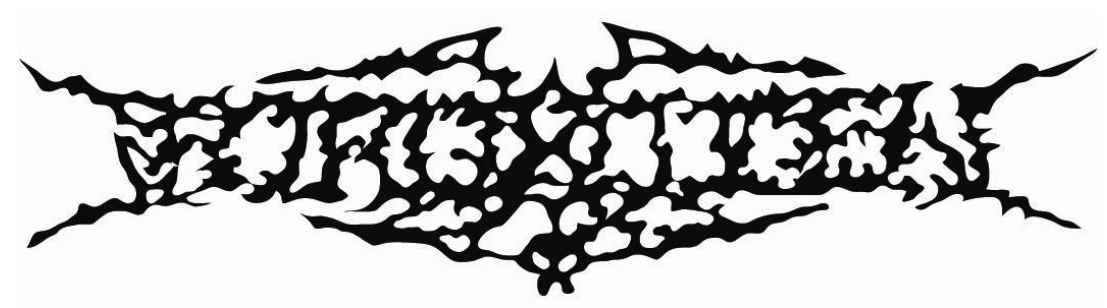

Gambar 8. Logotype Forgotten Pada Media Sampul Album “Obsesi Mati” [Sumber : Dokumentasi Atang Ryan Isnandar, 2013]

\section{a. Legibility}

Pada album "Obsesi Mati", logo band Forgotten dapat dikatakan tidak legible karena masing-masing huruf atau karakter dari logo Forgotten ini sulit dikenali, dapat dilihat dari adanya distorsi pada huruf yang begitu rumit atau seolah seperti akar. Selain itu pada huruf $\mathrm{F}$ dan huruf $\mathrm{N}$ terdapat ornamen akar yang lebih banyak / flag dibandingkan dengan huruf yang lain, serta terdapat penambahan ornamen khusus pada huruf $O$ yang menjadikan ketiga huruf tersebut semakin sulit untuk dikenali. 

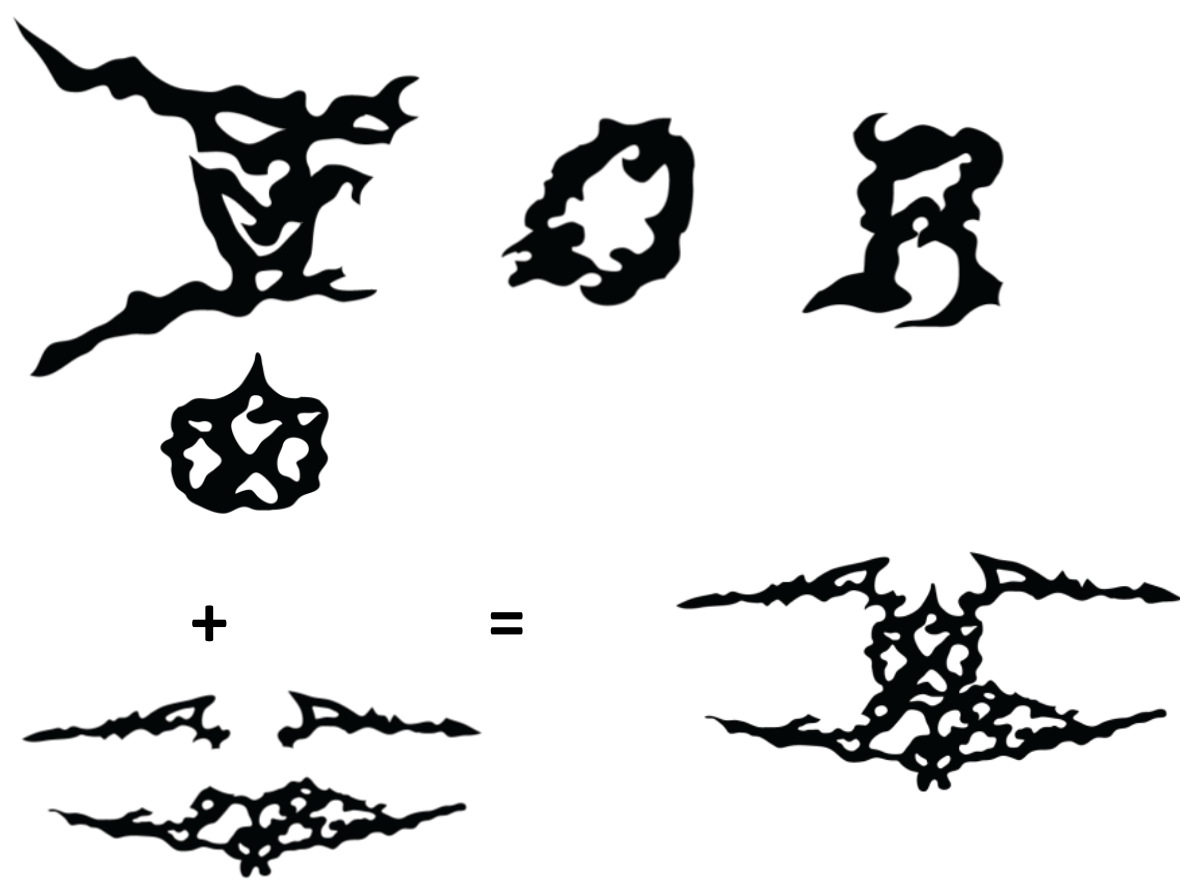

Gambar 9. Legibility pada logo band Forgotten pada album "Obsesi Mati" [Sumber : Dokumentasi Atang Ryan Isnandar, 2013]

\section{b. Readability}

Logo pada album "Obsesi Mati" memiliki tingkat readability yang sangat rendah. Tingkat kerumitan dari huruf dan kerning yang begitu rapat ditambahnya ornamen akar untuk menyambungkan setiap hurufnya menjadikan logo band Forgotten pada album "Obsesi Mati"ini tidak readible.

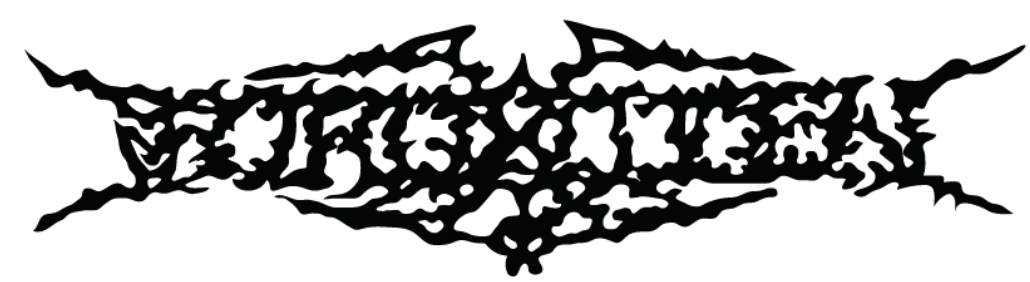

Gambar 10. Readability pada logo band Forgotten pada album "Obsesi Mati" [Sumber : Dokumentasi Atang Ryan Isnandar, 2013]

c. Visibility

Visibility tentunya berkaitan dengan jarak pandang, untuk logo band Forgotten pada album "Obsesi Mati"sudah tidak visible. 

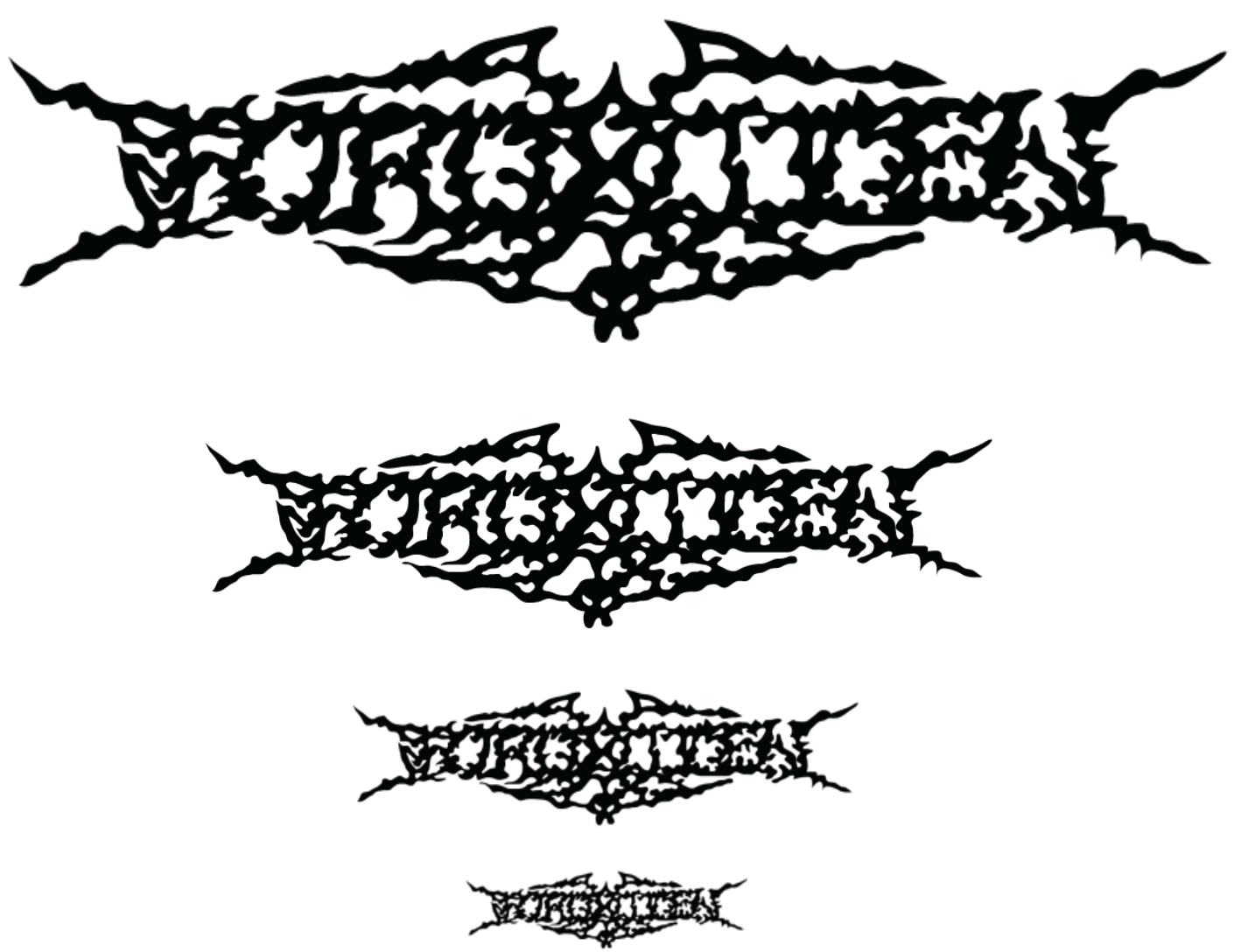

Gambar 11. Visibiliy pada logo band Forgotten pada album "Obsesi Mati"

[Sumber : Dokumentasi Atang Ryan Isnandar, 2013]

Dengan percobaan pada jarak $60 \mathrm{~cm}$ logo ini akan sangat sulit untuk dibaca, dengan jarak lebih dari $200 \mathrm{~cm}$ logo ini sudah tidak dapat dikenali bentuk maupun huruf yang terdapat pada logo tersebut.

\subsection{Analisis Logotype Forgotten Pada Sampul Album "Tuhan Telah Mati"}

Album "Tuhan Telah Mati" adalah album ketiga Forgotten yang berisi empat buah lagu dengan lirik berbahasa Indonesia dan dilaunching pada bulan Agustus 2001. Mini album tersebut dirilis di bawah perusahaan indie lokal bernama Rock Record. Pada album ini, logotype Forgotten didesain oleh Sule. Huruf yang ditampilkan pada logotype berjenis sans serif yang tampak lebih sederhana dari album-album sebelumnya. Pada sampul depan, logotype ditempatkan di atas sampul album. 


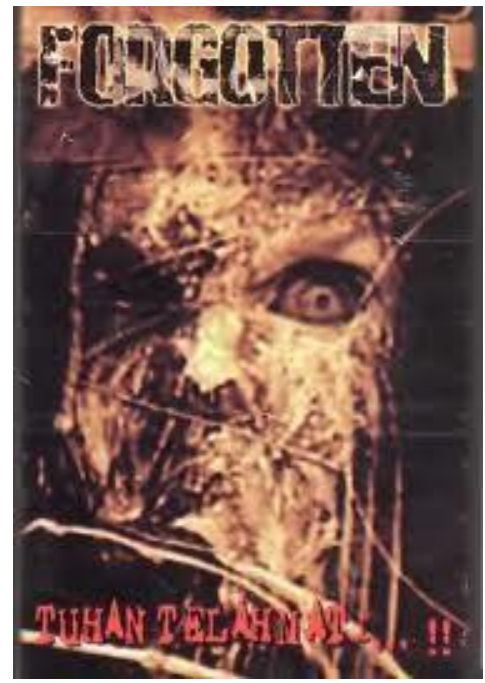

Gambar 12. Sampul Album "Tuhan Telah Mati"

[Sumber : http://bandung-underground.com/wp-content/uploads/2012/02/tuhan-telah-mati.jpg (18 April 2013)]

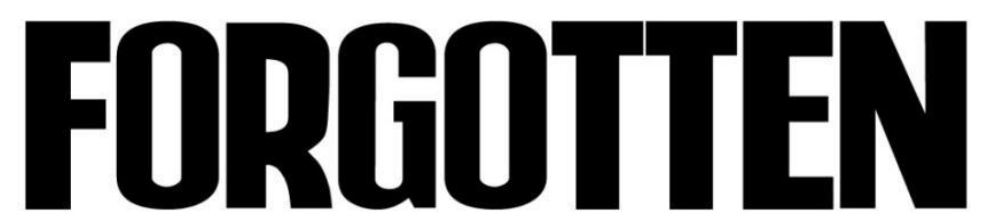

Gambar 13. Logotype Forgotten Pada Media Sampul Album "Tuhan Telah Mati" [Sumber : Dokumentasi Atang Ryan Isnandar, 2013]

\section{a. Legibility}

Pada album "Tuhan Telah Mati", logotype band Forgotten memiliki tingkat legibility yang baik. Logo band Forgotten pada album ini dapat dikatakan legible karena bentuk dari hurufnya mudah dikenali, hal ini disebabkan oleh tidak adanya distorsi huruf yang rumit.
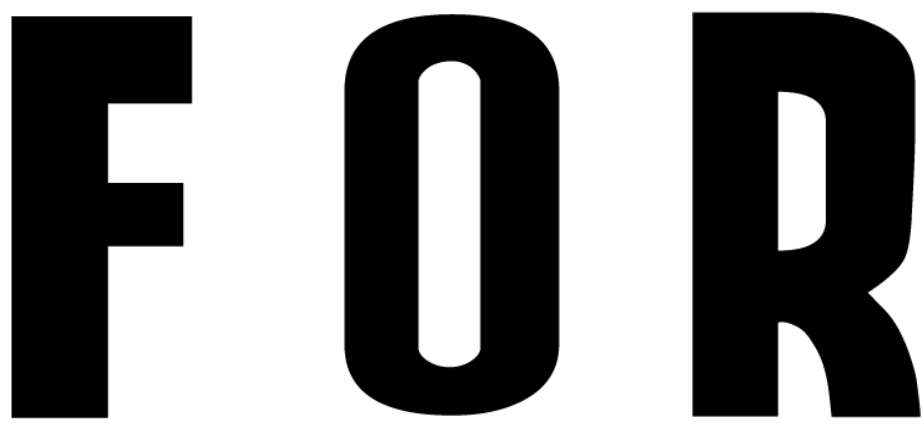

Gambar 14. Legibility pada logo band Forgotten pada album "Tuhan Telah Mati" [Sumber : Dokumentasi Atang Ryan Isnandar, 2013] 


\section{b. Readability}

Tingkat readability untuk logo band Forgotten pada album ini juga terbilang baik. Meskipun kerning yang terdapat pada logo ini memiliki jarak yang cukup rapat namun tingkat legibility-nya baik, sehingga menjadikan logo ini dapat mudah terbaca. Dalam album ini, logotype ditambahkan dengan adanya efek-efek seperti glow, gambar dan kesan hancur. Namun karena tingkat legible-nya baik, logo ini dapat dikatakan readible atau masih dapat terbaca dengan cukup baik.

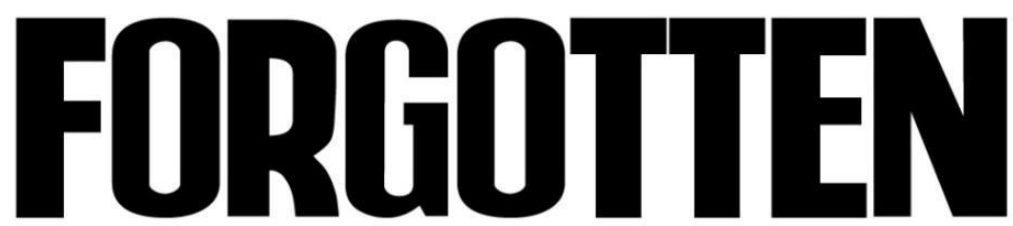

Gambar 15. Readability pada logo band Forgotten pada album "Tuhan Telah Mati" [Sumber : Dokumentasi Atang Ryan Isnandar, 2013]

c. Visibility

Logotype pada album "Tuhan Telah Mati" memiliki tingkat visibility yang cukup baik, dengan jarak kurang dari $60 \mathrm{~cm}$ logo ini dapat dengan mudah terbaca, untuk jarak lebih dari $200 \mathrm{~cm}$ logo ini kurang terbaca dikarenakan kerningnya cukup rapat, namun walaupun dilihat dalam jarak yang cukup jauh, logo ini masih bisa dikenali dikarenakan tingkat legibility-nya cukup baik.

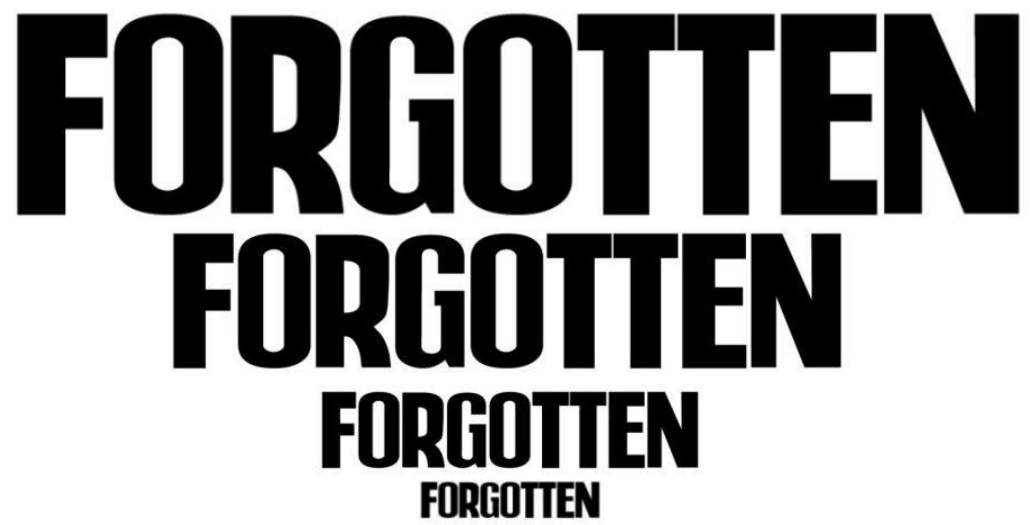

Gambar 16. Visibility pada logo band Forgotten pada album "Tuhan Telah Mati" [Sumber : Dokumentasi Atang Ryan Isnandar, 2013]

\subsection{Analisis Logotype Forgotten Pada Sampul Album "Tiga Angka Enam"}

Pada bulan Maret 2003 Forgotten merilis album "Tiga Angka Enam" dibawah label Rottrevore Records. Perancangan logotype band Forgotten pada sampul album "Tiga Angka Enam" ini melibatkan dua orang desainer yaitu Opick yang juga merupakan designer logotype pada album kedua Forgotten dan Andri salah satu personil dari band Siksa Kubur. Penempatan logotype-nya di album ini adalah center pada sampul album dengan posisi horisontal. 


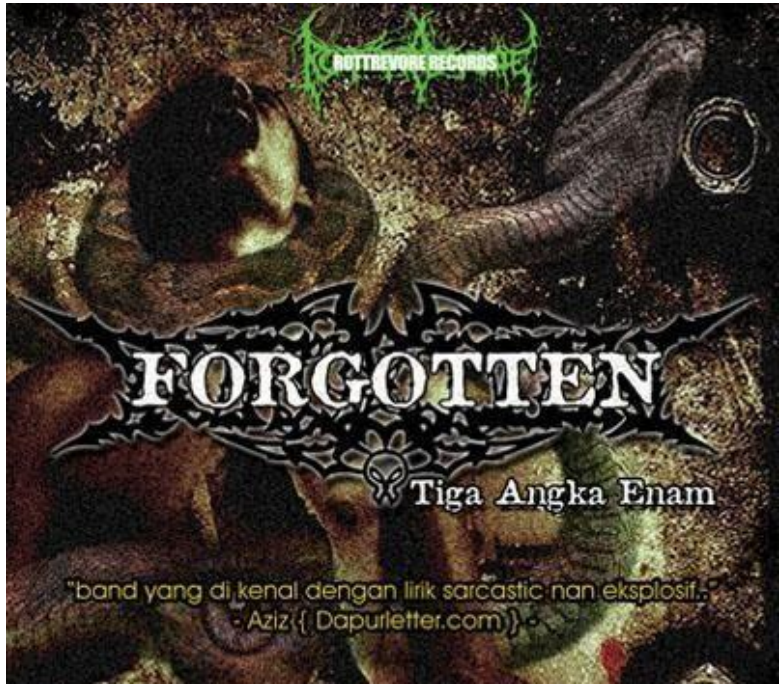

Gambar 17. Sampul Album "Tiga Angka Enam"

[Sumber:http://1.bp.blogspot.com/_SEoYfrShLzs/S3xKVJFSsJI/AAAAAAAAB5k/ sMOMQdtKek0/s320/Forgotten+-+Tiga+Angka+Enam+\%5B2008\%5D.jpg(18 April 2013)]

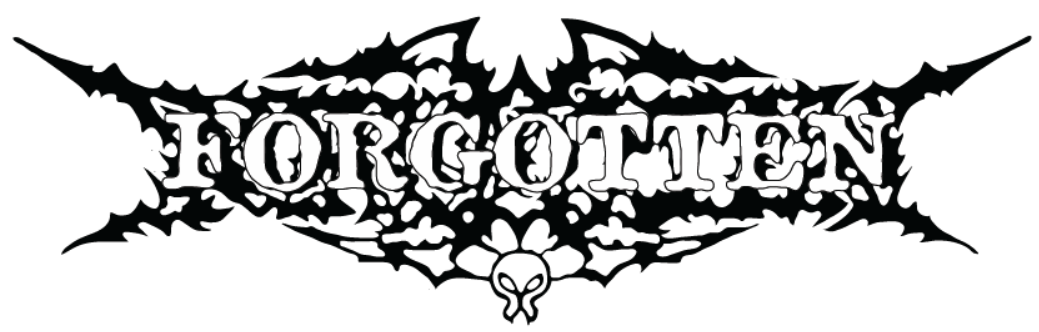

Gambar 18. Logotype Forgotten Pada Media Sampul Album “Tiga Angka Enam”

[Sumber : Dokumentasi Atang Ryan Isnandar, 2013]

\section{a. Legibility}

Logo pada sampul album "Tiga Angka Enam" memiliki tingkat legibility yang cukup baik. Meskipun pada setiap huruf adanya distorsi, namun distorsi tersebut cukup wajar, sehingga logotype band Forgotten pada sampul album ini masih dalam kategori legible.

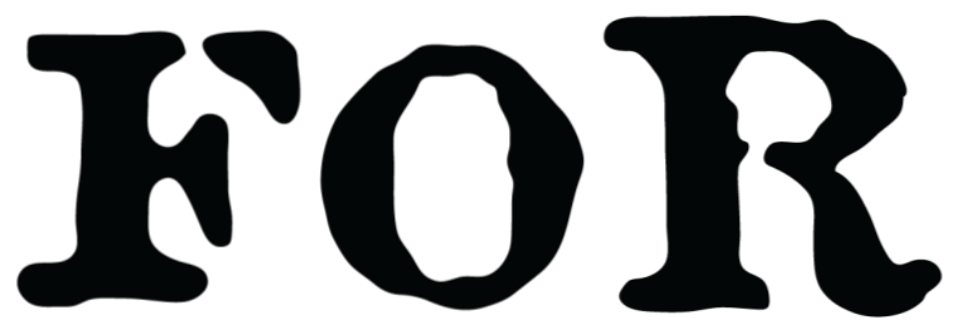

Gambar 19. Legibility pada logo band Forgotten pada album "Tiga Angka Enam" [Sumber : Dokumentasi Atang Ryan Isnandar, 2013] 


\section{b. Readability}

Tingkat Readability logo band Forgotten pada sampul album "Tiga Angka Enam" ini cukup baik. Bentuk dari huruf yang jelas dan kerning yang tidak terlalu rapat menjadikan logo ini dapat mudah dibaca.

\section{FORGOTTEN}

Gambar 20. Readability pada logo band Forgotten pada album "Tiga Angka Enam"

[Sumber : Dokumentasi Atang Ryan Isnandar, 2013]

Namun ada penambahan ornamen pada logo band Forgotten, penambahan ornamen pada tipografi ini menjadikan berkurangnya tingkat readability. Meskipun readability-nya berkurang, namun dikarenakan contrast yang tebal, kerning yang cukup baik, dan desain huruf yang sederhana menjadikan logo ini masih dapat dikenali.

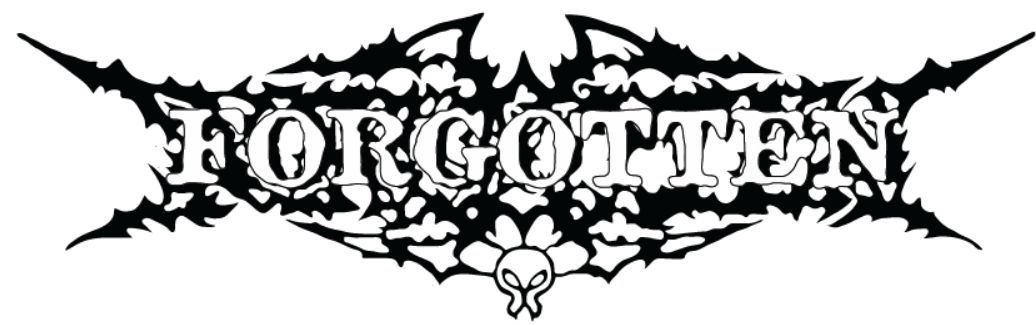

Gambar 21. Readability pada logo band Forgotten pada album "Tiga Angka Enam" dengan ornamen [Sumber : Dokumentasi Atang Ryan Isnandar, 2013]

c. Visibility

Logo band Forgotten yang terdapat pada sampul album Tiga Angka Enam memiliki tingkat visibility yang tidak baik. Dengan jarak pandang kurang dari $60 \mathrm{~cm}$ logo ini cukup terbaca karena tingkat legibility dari hurufnya cukup baik. Untuk jarak lebih dari $200 \mathrm{~cm}$ logo ini sudah tidak dapat terbaca, dikarenakan ornamen yang terdapat pada logo ini lebih mendominasi dibandingkan dengan tipografinya.

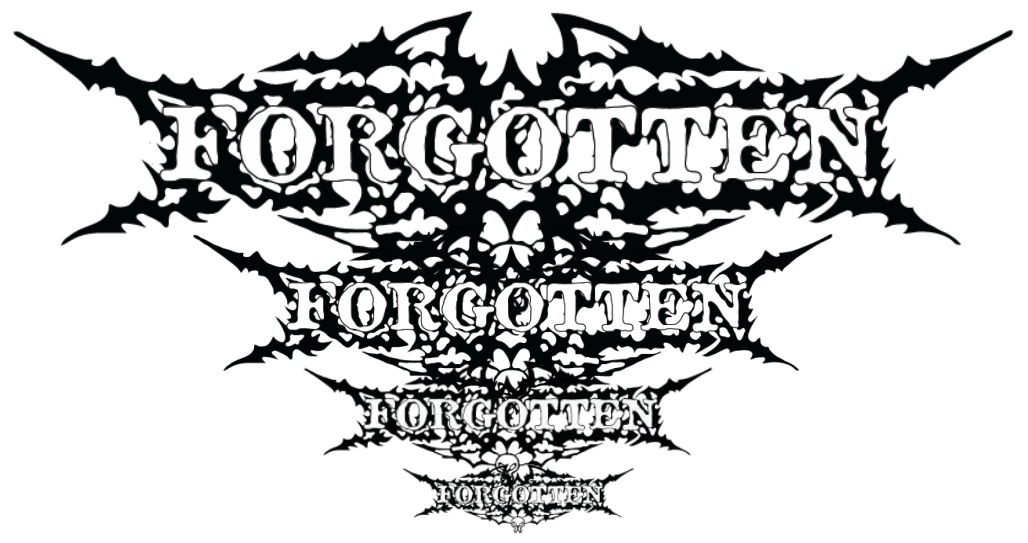

Gambar 22. Visibility pada logo band Forgotten pada album "Tiga Angka Enam” dengan ornamen [Sumber : Dokumentasi Atang Ryan Isnandar, 2013] 


\subsection{Analisis Logotype Forgotten Pada Sampul Album "Laras Perlaya"}

"Laras Perlaya" adalah titel dari album Forgotten yang dirilis oleh Rock Records pada tahun 2011. Album ini adalah album ke-5 bagi Forgotten yang telah berdiri sejak tahun 1994. Dalam album ini juga ikut disertakan sebuah novel yang dilengkapi dengan ilustrasi engraving karya Dinan Art yang memberikan penjabaran terhadap setiap makna lirik.

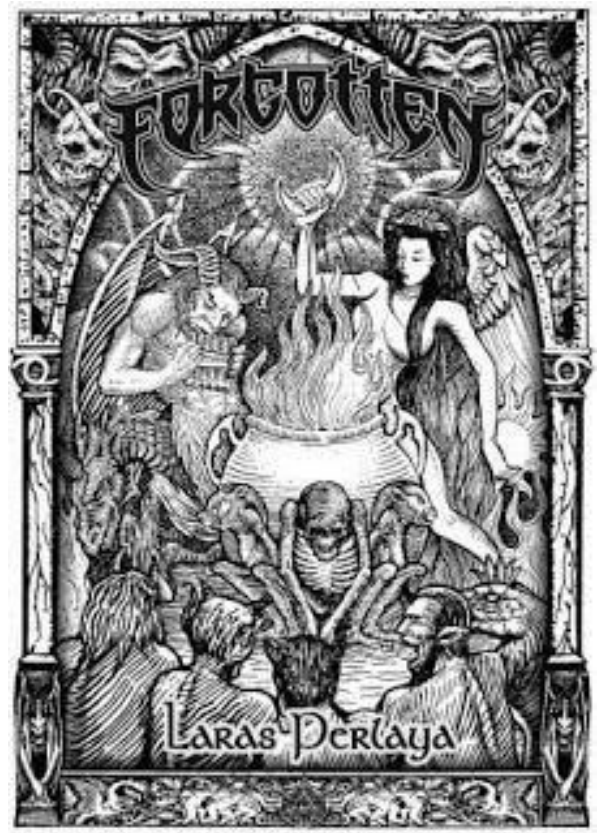

Gambar 23. Sampul Album "Layar Perlaya”

[Sumber : http://1.bp.blogspot.com/SEoYfrShLzs/S3xKVJFSsJI/AAAAAAAAB5k/sMO MQdtKek0/s320/Forgotten+-+Tiga+Angka+Enam+\%5B2008\%5D.jpg (18 April 2013)]

Yusep merupakan desainer logotype pada sampul album "Laras Perlaya". Logotype ini didesain dengan konsep black and white, dan pada sampul ditempatkan pada bagian atas sampul album dan dibuat sedikit melengkung.

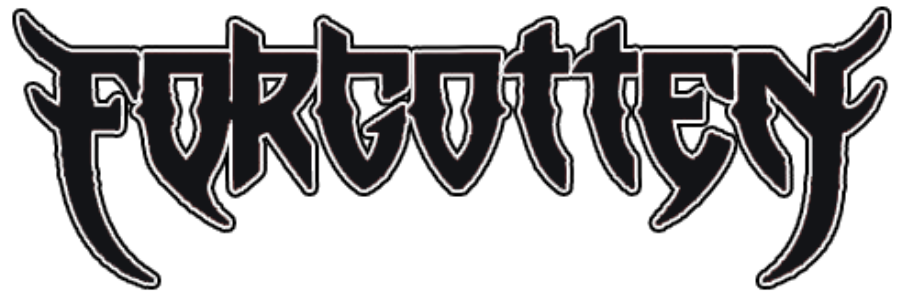

Gambar 24. Logotype Forgotten Pada Media Sampul Album "Layar Perlaya" [Sumber : Dokumentasi Atang Ryan Isnandar, 2013] 


\section{a. Legibility}

Pada sampul album "Laras Perlaya", logotype band Forgotten ini memiliki tingkat legibility yang cukup baik, meskipun terdapatnya distorsi huruf pada logo ini, namun karena kontras yang cukup dan desain huruf yang tidak rumit menjadikan huruf pada logo ini mudah dikenali sehingga dapat dikatakan legible.
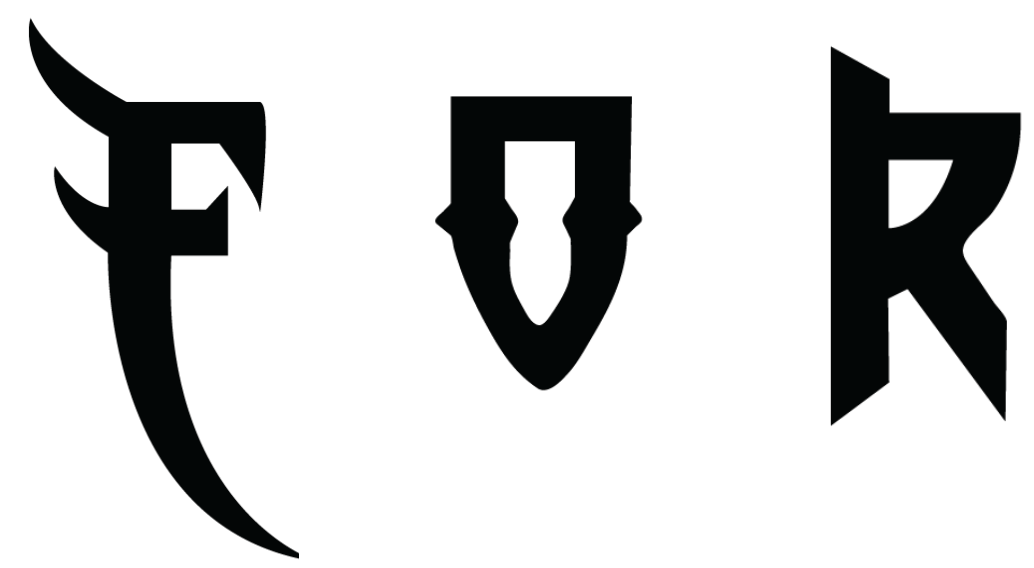

Gambar 25. Legibility pada logo band Forgotten pada Album "Layar Perlaya” [Sumber : Dokumentasi Atang Ryan Isnandar, 2013]

\section{b. Readability}

Logotype pada album ini dapat dikatakan readable. Meskipun kerning cukup rapat serta adanya penambahan stroke dibagian luar pada pada logo ini, namun tidak mengurangi tingkat keterbacaannya. Hal ini dikarenakaan logo ini memiliki legibility yang cukup baik dan desain huruf yang tidak rumit.

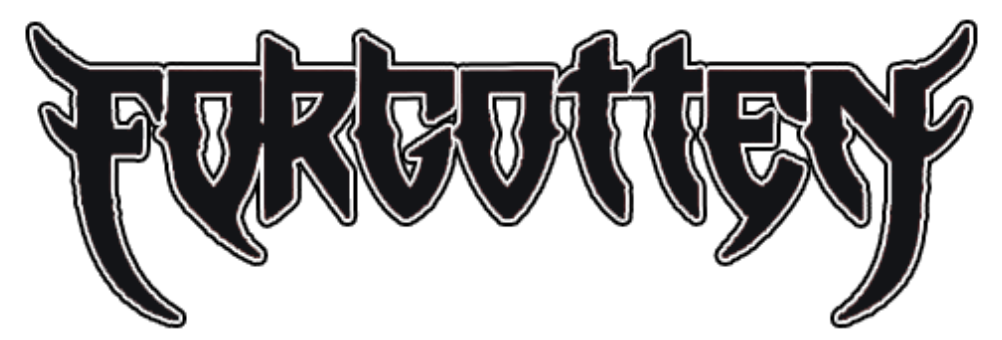

Gambar 26. Readability pada logo band Forgotten pada album "Layar Perlaya" dengan ornamen [Sumber : Dokumentasi Atang Ryan Isnandar, 2013]

c. Visibility

Untuk jarak kurang dari $60 \mathrm{~cm}$ logo yang terdapat pada sampul album "Laras Perlaya" dapat dikatakan visible, namun meskipun memiliki tingkat legibility dan readability yang baik namun karena kerning yang rapat dan adanya tambahan stroke dibagian luar menyebabkan logo ini tidak lagi visible ketika jarak pandang lebih dari $200 \mathrm{~cm}$. 


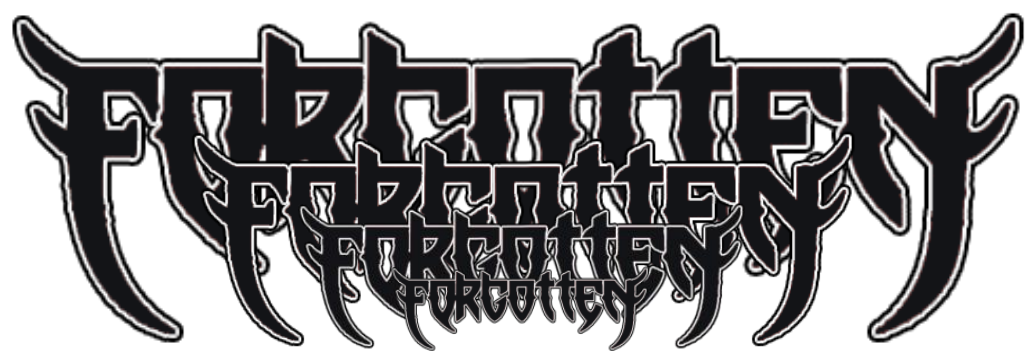

Gambar 27. Visibility pada logo band Forgotten pada album "Layar Perlaya" dengan ornamen [Sumber: Dokumentasi Atang Ryan Isnandar, 2013]

\section{KESIMPULAN}

Berdasarkan hasil pembahasan, logotype Forgotten di album "Future Syndrome", "Obsesi Mati", "Tuhan Telah Mati", "Tiga Angka Enam" dan "Laras Perlaya" memiliki memiliki tingkat legibility, readability dan visibility yang berbeda-beda. Logotype pada album "Tuhan Telah Mati" dan "Layar Perlaya" misalnya memiliki tingkat yang cukup baik dari sisi kejelasan, keterbacaan, dan jarak pandang. Sedangkan logotype pada album "Future Syndrome" , "Obsesi Mati" dan "Tiga Angka Enam" memiliki tingkat kejelasan, keterbacaan, dan jarak pandang yang kurang/tidak baik. Hal-hal tersebut disebabkan karena pengaruh jenis, struktur huruf, jarak antar huruf dan elemen visual lain (seperti ornamen). Tingkat legibility, readability dan visibility yang berbeda-beda, pada akhirnya memunculkan kesan visual yang berbeda pula.

Berdasarkan penelitian ini, penulis merekomendasikan agar perancangan sebuah logotype tidak hanya mengedepankan sisi estetika semata namun juga harus tetap memperhatikan prinsip tipografi agar fungsi logotype lebih maksimal.

\section{DAFTAR PUSTAKA}

\section{Buku}

Kusrianto, Adi. (2009). Pengantar Desain Komunikasi Visual. Yogyakarta : Penerbit ANDI

Rustan, Surianto. (2009). Layout : Dasar \& Penerapannya. Jakarta : Gramedia Pustaka Utama.

Rustan, Surianto. (2009). Mendesain Logo. Jakarta : Gramedia Pustaka Utama.

Rustan, Suryanto. (2011). Font \& Tipografi. Jakarta : Gramedia Pustaka Utama.

Sihombing, Danton. (2003). Tipografi Dalam Desain Grafis. Jakarta : Gramedia Pustaka Utama.

\section{Skripsi}

Riyan, Atang. (2013). Analisis Dan Persepsi Visual Tipografi Pada Logo Band Forgotten (Studi Kasus : Sampul Album Future Syndrome, Obsesi Mati, Tuhan Telah Mati, Tiga Angka Enam Dan Laras Perlaya). Bandung : UNIKOM. 


\section{Internet}

ADS. (2013). Elemen-elemen Dalam Desain Komunikasi Visual. Tersedia di: http://www.ahlidesain.com/elemen-elemen-dalam-desain-komunikasivisual.html [11 April 2013]

Facebook Forgotten. (2013). Forgotten. Tersedia: http://www.facebook.com/666forgotten666 [15 April 2013]l

Metal (2012). Biografi Band Forgotten. Tersedia di : http://biografiband.web.id/2012/08/biografi-band-forgotten.html [13 April

2013]

REVERBNATION. (2013). Band Forgotten. Tersedia di :

http://www.reverbnation.com/forgotten666 [13 April 2013] 